\title{
A study on the protective effects of green tea catechins on heart exposed to microwave induced oxidative damage of male albino rat
}

\author{
Mahmoud A. EL-Gharieb; Romysaa A. EL-Sherbeny \\ Department of Physiology, Faculty of Medicine \\ Tanta University
}

\begin{abstract}
The present work was carried out to investigate the effects of green tea catechin on oxidative damage in microwave exposed male albino rats. The rats were divided into three equal groups each composed of 7 rats. The first group was the control one. The second group was the microwave exposed for 10 minutes for 6 days. The third group rats were exposed to microwave for 6 days and received catechin in a dose of $7 \mathrm{gm} /$ diet during microwave exposure which was extended for 4 weeks after exposure. At the end of the experiment the rats were sacrificed and the hearts were dissected and heart microsomes were prepared.

The results of the work showed significant increase by microwave exposure in the levels of cytochrome $P_{450}$ and $N A D P H$ reductase activity that were significantly reduced by catechin supplementation. Significant reduction by microwave in superoxide dismutase glutathione peroxidase and catalase were increased significantly by catechin. The levels of superoxide radical, lipid peroxide and carbonyl value were significantly increased by microwave exposure and were improved by catechin supplementation. The lipofuscin content of heart was also increased by microwave exposure and was improved by catechin supplementation.

It is concluded that, the mixed function oxidase system were activated by microwave exposure, the formation of superoxide radical, lipid peroxide, oxidized protein and lipofuscin were increased and the antioxidative defense system was weakened in heart tissue, but the oxidative damage was significantly reduced by catechin supplementation.
\end{abstract}

\section{INTRODUCTION}

It is well known that exposure to electromagnetic waves has various harmful effects in living organism ${ }^{(1)}$. In particular, high frequencies, such as microwaves involve a substantial amount of energy, and exposure to microwaves has been found to have a harmful effect on actively dividing cells, such as reproductive organs, cardiac and pulmonary tissue and white blood corpuscles ${ }^{(1)}$.

Also it is associated with various morbidities ${ }^{(2)}$.

The analysis of other studies ${ }^{(3)}$ and preceding basic research is likely that microwave toxicity is caused by reactive oxygen species 
(ROS) generated during oxidization $^{(4)}$. It was previously reported that mixed function oxidase system was significantly increased and antioxidative enzyme activity was decreased with corresponding changes in gene expression ${ }^{(5)}$.

Lipid peroxide concentrations were also increased in rat liver exposed to microwaves ${ }^{(6)}$. It was observed that the toxicity of microwaves is due to damage by reactive oxygen species generated during oxidation and the chronic disease is related to free radical generation and oxidative stress ${ }^{(\mathbf{6})}$.

Heart tissue is especially susceptible to oxidative stresses such as exposure to microwaves, and when ROS exposure is excessive, diseases such as hypertension and cardiovascular dysfunction may occur. Therefore, when the heart is exposed to microwaves, there is a high risk of heart failure due to the increased generation of free radicals in the tissue $\mathrm{e}^{(7)}$. It was observed that some changes in the respiratory rate and heart rate and an increase in arterial blood pressure occur in rats irradiated with microwaves ${ }^{(\mathbf{8})}$.

Furthermore, there was an increased circulatory system functional disorder in rats irradiated with microwaves which indicated that the cause was increased oxidative stress $^{(\mathbf{9})}$. On the other hand, ROS such as superoxide radical and hydroxyradical in living bodies are neutralized by anti oxidative defense enzymes such as superoxide dismutase, catalase and glutathione peroxidase $^{(\mathbf{1 0})}$. Nutritional antioxidants such as vitamin E, B, carotene, ascorbic acid and glutathione also protect against them ${ }^{(\mathbf{1 1})}$. However, when living bodies are exposed to excessive exogenous oxidative stress, by microwaves irradiation and metal toxication, or during increased endogenous oxidative stress that occurs in disease states, excessive free radicals accumulate, because of the imbalance between free radical generation and scavenging systems. The excessive accumulation of free radicals that occurs when the antioxidant system is weakened. Thus it is believed to be related to the etiology of age-related chronic disease and aging itself ${ }^{(\mathbf{1 1})}$. Accordingly, to be able to suppress oxidative damage by microwaves irradiation, it is important to understand how homeostasis is maintained between the related oxidative and antioxidative processes $^{(\mathbf{1 2})}$. Also, how to strengthen the antioxidative defense system and weaken the free radical generation system using antioxidant substances such as vitamin $\mathrm{E}$ and selenium ${ }^{\mathbf{( 1 2 )}}$.

The polyphenol compound catechin, found in green tea has been reported to have antioxidant action and free radical scavenging function, because of their very potent antioxidative capacity $^{(\mathbf{1 3})}$. Reactive oxygen species such as $\mathrm{O}_{2}, \mathrm{OH}$ and $\mathrm{H}_{2} \mathrm{O}_{2}$ activate the initiation and promotion stage of cancer, as well as damage of the cell membrane DNA. Green tea catechin suppresses free radical generation ${ }^{(\mathbf{1 4})}$. Also catechin acts as a strong antioxidative substance by increasing the gene expression and activity of antioxidative defense enzymes that protect against lipid peroxidation in rat liver exposed to microwave ${ }^{(6)}$. 
This study aims to elucidate the changes in mixed function oxidase system and antioxidative defence system in heart tissue of albino rats exposed to microwave radiation, and to study the protective antioxidative effects of green tea catechins.

\section{MATERIALS \& METHODS}

21 Male albino rats of about 200250 gm were used and fed with normal diet for one week and then divided to three equal groups:

\section{Group 1:}

The control group consisted of 7 rats fed on normal diet.

\section{Group 2:}

The microwave exposed group consisted of 7 rats. The experimental instrument included a high frequency generator that was designed to be available for remote control to optionally adjust both output and exposure time (Model 8594 EM). The maximum dose rate after 15 minutes exposure $^{(15)}$. For 6 days.

Group 3:

It consisted of 7 rats. The rats were exposed to microwave for 6 days and at the same time receiving diet containing crude catechin powder from green tea in a dose of 7 gm/diet ${ }^{(\mathbf{1 6})}$, which was maintained for a period of 4 weeks.

At the end of the experiment the rats were sacrificed on the six day after microwaves irradiation as the oxidative damage is most servered at this period ${ }^{(6)}$ and after 4 weeks for group 3 (microwave and catechin). After sacrificing the animals, the heart was dissected, washed with $0.9 \% \mathrm{Na}$ $\mathrm{CL}$, quick-frozen in liquid hydrogen and stored. Heart microsomes were prepared by the biochemical method of Choi et al. ${ }^{(\mathbf{1 7})}$. Cytochrome $\mathrm{P}_{450}$ level in heart tissue was measured by the method of Omura and Sato ${ }^{\mathbf{( 1 8 )}}$.

The activity of NADPH Cytochrome $\mathrm{P}_{450}$ reductase in the heart was measured according to the method of Masters et al. ${ }^{\mathbf{( 1 9 )}}$.

Superoxide dismutase (SOD) activity in heart tissue was measured with the methods of Markland and Markland ${ }^{(20)}$.

The activity of glutathione peroxidase in heart tissue was measured according to the method of Lawrence and Burk ${ }^{(21)}$. The superoxide radical in heart tissue was measured with the methods of Azzi et al. $^{(22)}$. Lipid peroxide concentrations in heart tissue were measured according to the method of Satoh ${ }^{(23)}$, which measures malondialdehyde. Protein determination in the heart was measured by the of Lowery et al. ${ }^{(24)}$.

\section{Statistical Analysis}

The data obtained in this study were expressed as mean $\pm \mathrm{SE}$. The data were analyzed by use of standard statistical analysis, the one way ANOVA with Scheffe test for multiple comparisons to determine significance between different groups, values of $\mathrm{P}<0.05$ were considered significant .

\section{RESULTS}

The results of the present work showed in Table (1).

Significant increase in the levels of cytochrome $\mathrm{P}_{450}$ and NADPH reductase activities on exposure to microwave irradiation which were significantly reduced by catechin supplementation, Fig $(1,2)$. 
As regard the antioxidative defense system in heart tissue, superoxide dismutase and glutathione proxidase and catalase were reduced by microwave irradiation and significantly increased by catechin supplementation, Fig $(3,4)$.

The levels of superoxide radical, lipid peroxidse and carbonyl value were significantly increased by microwave exposure and improved by green tea catechin supplementation, Fig $(5,6,7)$.

Also, lipofuscin content of the heart tissue was significantly increased by microwave irradiation and improved by catechin supplementation, Fig (8).

Table (1) Effect of green tea catechin on cytochrome $P_{450}, N A D P H$, superoxide dismutase and glutathione proxidase, superoxide radicals, thiobarbituric acid, lipofucin and carbonyl value of albino rat heart exposed to microwave

\begin{tabular}{|c|c|c|c|}
\hline Parameter & Normal & Microwave & Microwave + Catechin \\
\hline \multicolumn{4}{|c|}{ Cytochrome $\mathrm{P}_{450}(\mathrm{n} \mathrm{mol} / \mathrm{mg}$ of protein / minute $)$} \\
\hline Mean $(\mathrm{m}=7)$ & 0.21 & 0.34 & 0.3 \\
\hline SE & 0.01 & 0.01 & 0.006 \\
\hline $\mathrm{T}$ & & $13 *$ & $9 *$ \\
\hline \multicolumn{4}{|c|}{ NADPH ( $\mathrm{n} \mathrm{mol} / \mathrm{mg}$ of protein / minute ) } \\
\hline Mean $(\mathrm{m}=7)$ & 3.08 & 4.02 & 3.51 \\
\hline SE & 0.04 & 0.05 & 0.1 \\
\hline $\mathrm{T}$ & & $15.6 *$ & $4.3^{*}$ \\
\hline \multicolumn{4}{|c|}{ Superoxide dismutase ( unite / mg of protein / minute ) } \\
\hline Mean $(\mathrm{m}=7)$ & 5.64 & 3.84 & 4.98 \\
\hline SE & 0.1 & 0.13 & 0.16 \\
\hline $\mathrm{T}$ & & $11 *$ & $3.6 *$ \\
\hline \multicolumn{4}{|c|}{ Glutathione proxidase ( nmol of NADPH / mg of protein / minute ) } \\
\hline Mean $(\mathrm{m}=7)$ & 201.28 & 148.85 & 249.14 \\
\hline SE & 2.77 & 3.53 & 6.3 \\
\hline $\mathrm{T}$ & & $11.7 *$ & $6.9 *$ \\
\hline \multicolumn{4}{|c|}{ Superoxide radical ( $\mathrm{n} \mathrm{mol} / \mathrm{mg}$ of protein / minute ) } \\
\hline Mean $(\mathrm{m}=7)$ & 8.87 & 12.5 & 10.3 \\
\hline SE & 0.3 & 0.53 & 0.18 \\
\hline $\mathrm{T}$ & & $6 *$ & $4.2 *$ \\
\hline \multicolumn{4}{|c|}{ Thiobarbituric acide reactive Substances (n mol/mg protein) } \\
\hline Mean $(\mathrm{m}=7)$ & 0.18 & 0.38 & 0.28 \\
\hline SE & 0.008 & 0.008 & 0.006 \\
\hline $\mathrm{T}$ & & $20 *$ & $10 *$ \\
\hline \multicolumn{4}{|c|}{ Lipofucin ( ug/mg protein ) } \\
\hline Mean $(m=7)$ & 5.05 & 7.2 & 5.61 \\
\hline SE & 0.09 & 0.13 & 0.13 \\
\hline $\mathrm{T}$ & & $14.3 *$ & $3.7 *$ \\
\hline \multicolumn{4}{|c|}{ Carbonyl value ( ug/mg protein ) } \\
\hline Mean $(m=7)$ & 77.1 & 90.9 & 81.8 \\
\hline SE & 0.54 & 0.89 & 0.74 \\
\hline $\mathrm{T}$ & & $9.7^{*}$ & $5.1 *$ \\
\hline
\end{tabular}

* = Denotes statistical significance $(\mathrm{P}<0.05)$. 
Fig (1): Effect of green tea catechin on cytochrome P45o of albino rat heart exposed to microwave

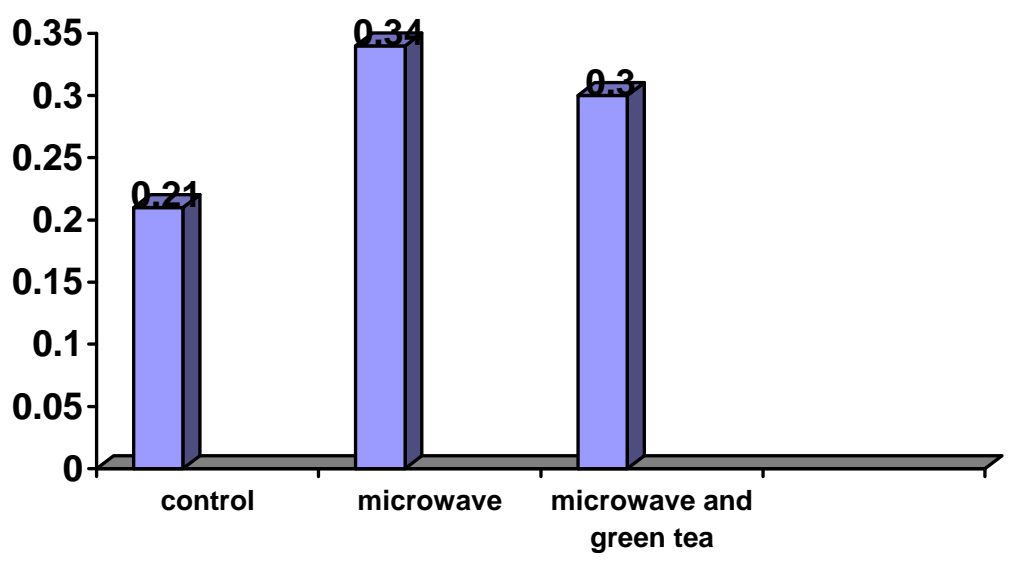

Fig (2): Effect of green tea catechin on NADPH of albino rat heart exposed to microwave

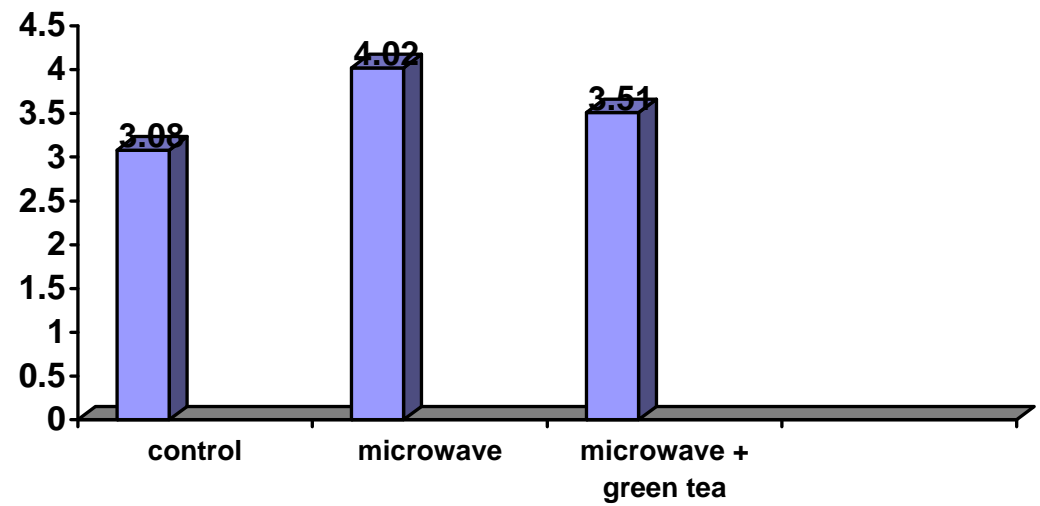


Fig (3): Effect of green tea catechin on superoxide dismutase content of albino rat heart exposed to microwave

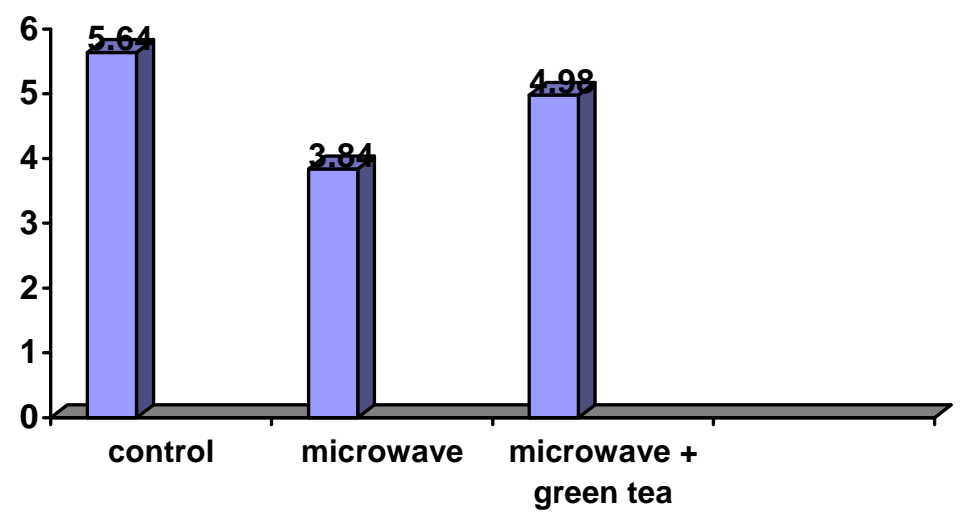

Fig (4) Effect of green tea catechin on glutathione (GSHPx) content of albino rat heart exposed to microwave

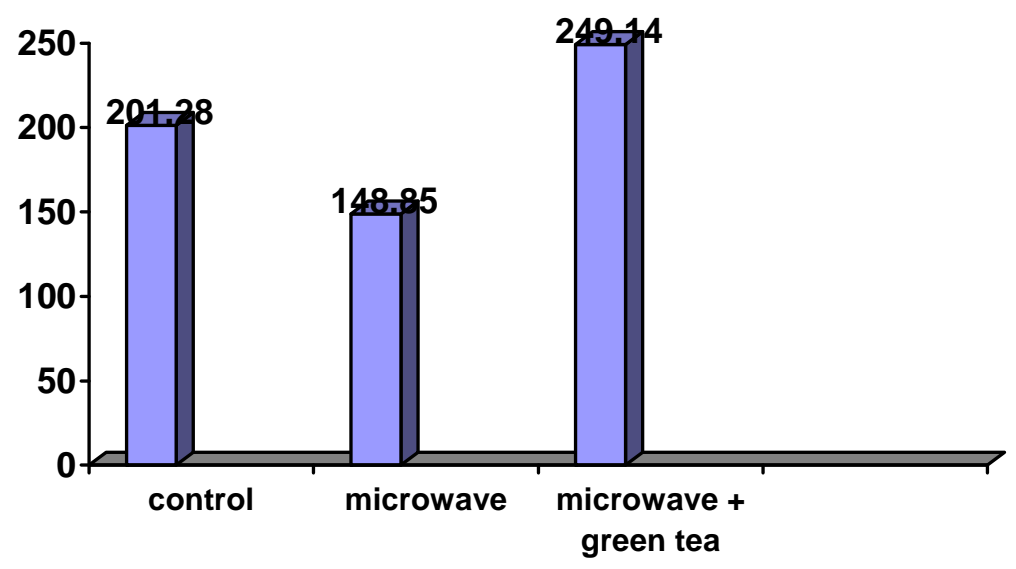


Fig (5): Effect of green tea catechin on superoxide radical of albino rats heart exposed to microwave

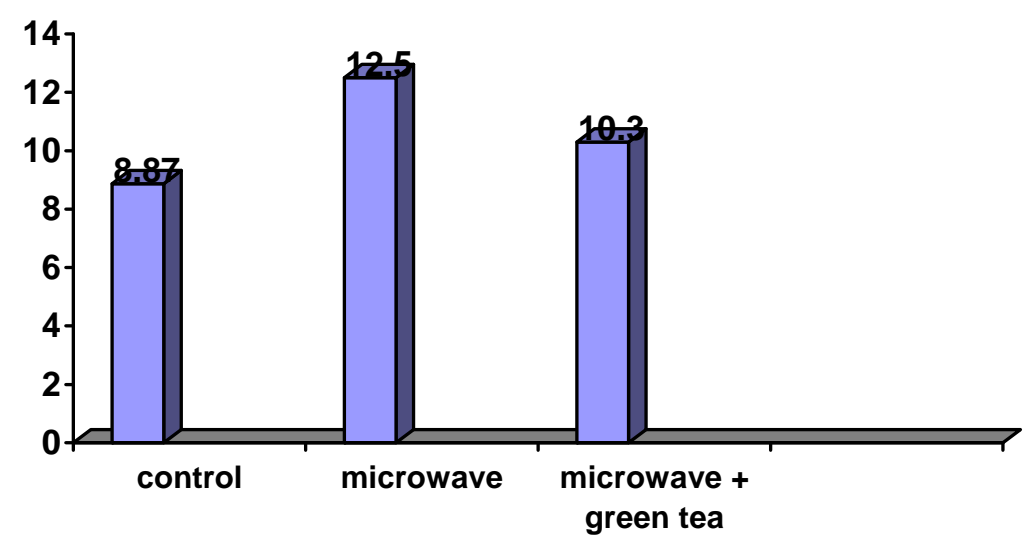

Fig (6): Effect of green tea catechin on (TBARS) thiobarbituric acid reactive substances of albino rat heart exposed to microwave

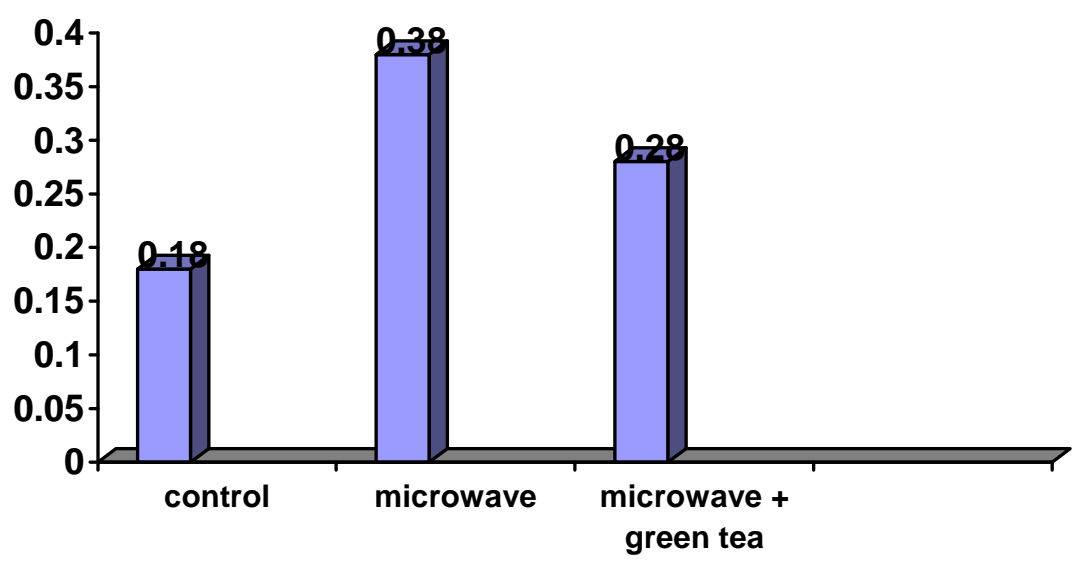


Fig (7): Effect of green tea catechin on lipofucin content of albino rat heart exposed to microwave

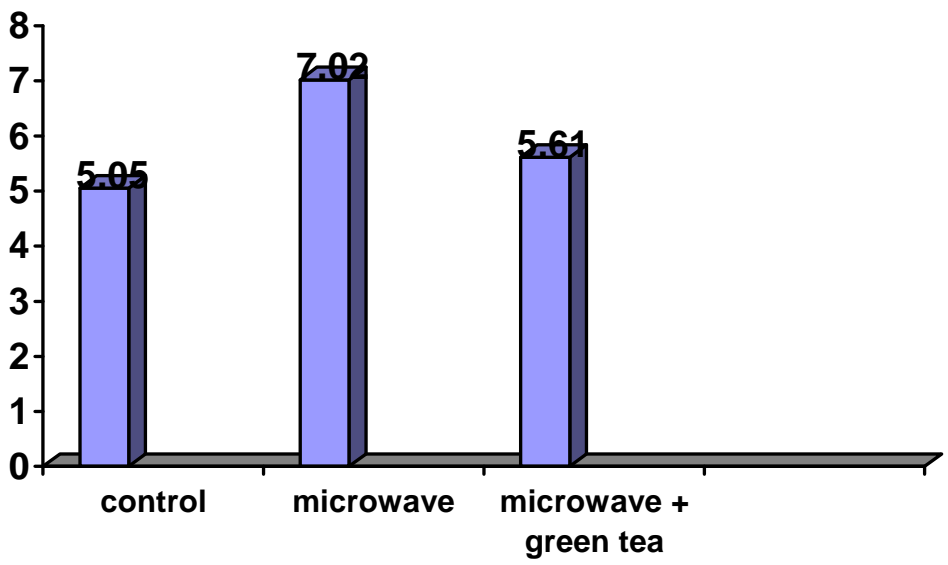

Fig (8): Effect of green tea catechin on carbonyl value of albino rat heart exposed to microwave

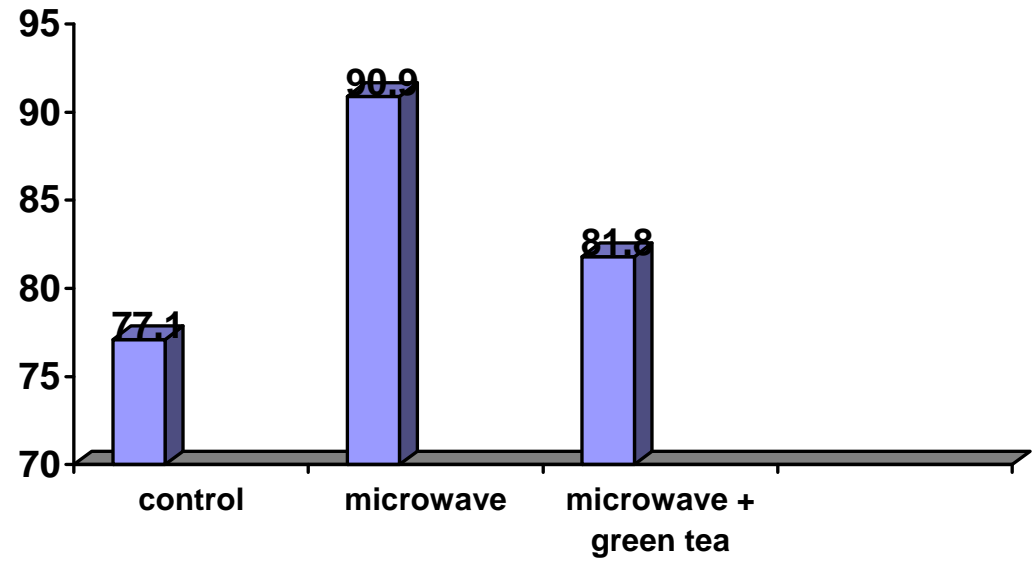




\section{DISCUSSION}

This study was conducted to observe the antioxidative effect of green tea catechin in microwaveexposed albino rats. Microwaveexposed rats with or without supplemental green tea catechin were observed for any change in the mixed function oxidase system and oxidative defense systems in the heart tissue, as well as for the generation of superoxide radical and oxidative damage $^{(24)}$.

The mixed function oxidative system generates $\mathrm{O}_{2}$ and $\mathrm{H}_{2} \mathrm{O}_{2}$ during the detoxification process of endogenous carcinogens and exogenous toxic material, thereby inducing oxidative damage of the tissue. The present work showed significant increase in cytochrome $\mathrm{P}_{450}$ levels in microwave exposed group compared to control one. These results are similar to those reported by Kim et al. (5), who showed that hepatic cytochrome $\mathrm{P}_{450}$ levels could be increased by microwave irradiation . The evaluation of the effect of irradiation in whole living animals and the demonstration that exogenous toxic material and irradiation have profound effects on endogenous steroid and other hormones, so an increase in cytochrome $\mathrm{P}_{450}$ level is a normal physiological response to environmental stresses, such as microwave irradiation $^{(25)}$.

The result of the present work showed significant increase in NADPH cytochrome $\mathrm{P}_{450}$ reductase activity, which was significantly reduced by administration of catechin. These results demonstrated that when the living bodies are exposed to exogenous stress, enzymes related to detoxification process are activated to protect organism and maintain survival. Since catechin acts as an antioxidant, the mixed function oxidase system activity was reduced because of reduced toxication as a result of catechin supplementation ${ }^{(5)}$.

Moreover, the superoxide radical generation was increased by microwave exposure because of increased oxidative stress and mixed function oxidase system. However, catechin supplementation reduced free radical generation and the effects of the mixed function oxidase system superoxide dismutase reduces the superoxide radical to $\mathrm{H}_{2} \mathrm{O}_{2}$ which is then neutralized by the action of glutathione peroxidase and catalase, therefore protects the living body from oxidative damage ${ }^{(6)}$. When cells are exposed to oxidative stress, proteins with protective capacity are activated, in particular, superoxide dismutase that operates as a first defense system against tissue damage by the radiation which was improved by catechin supplementation ${ }^{(6)}$. The results also indicated that peroxidation of unsaturated fatty acids in the existing membranes was activated by oxidative stress by microwave irradiation, thereby accelerating cell time damage and decreasing the enzyme activities. Kim et al. ${ }^{(6)}$ reported that microwave irradiation of rats reduced hepatic antioxidative defense enzyme activity and altered the gene expression of superoxide dismutase and glutathione peroxidase and catalase, but the green tea catechin supplementation restored the 
antioxidetive defense enzymes activity and gene expression.

Moreover, when rats were chronically exposed of microwave irradiation, there was a significant decrease in food consumption ${ }^{(26)}$. In addition, serum glutamic transaminase and glutamic oxalacetic transaminase activities were significantly increased $^{(26)}$. Lipid peroxide concentrations, which considerd an index of lipid peroxidation, were increased by microwave irradiation and improved by catechin supplementation. The same results were obtained with carbonyl and lipofusin which correspond with changes in the antioxidative defense system $^{(27)}$.

\section{CONCLUSION}

The mixed Function oxidase system when activated by microwave irradiation, leads to the increased formation of superoxide radical, lipid peroxide, oxidized protein and lipofuscin.

Also the antioxidative defense system was weakened in heart tissue. Therefore oxidative damage was increased by microwave exposure. However, green tea catechin supplementation significantly reduced oxidative damage by weakening of free radical generating system and strengthening of the antioxidative system.

\section{Acknowledgment}

For professor Tarek EL-Nimer, Professor of Physics and Atomic irradiation Faculty of Science, for his help in the research as regard for the control of the duration, frequency of microwave in his department of Physics in Tanta University.

\section{REFERENCES}

1. Charles PK. (1996): Effects of electromagnetic fields, CRC press, Boca Raton, FL, 185 - 239.

2. Lu ST, Lebda N. and Petti S. 1987: Effects of microwaves to three different strains of rats. Radiat Res. 110:173-191.

3. Bavincoba M. (1993): Microwave-induced lipid peroxidadtion in Liposomes. Foliabiol Praha, 39:250 - 255.

4. Chol JH, Shin HJ, Lee JH and Rhee SJ. (1998): Peroxidative damage in rat liver exposed to microwave . J. Korean Soc. Food SCI. Nutr., 27 : 1262 -1266.

5. Kim MJ, Lee JH and Rhee SJ. (2001): Effect of catechin on mixed function oxidase system and oxidative damage in rat liver exposed to microwave. Korean J. Nutr., 34:229-305.

6. Kim MJ, Cho JH, Kim SY, Kim $J H$, Lee JH and Rhee SJ. (2002): Effects of green tea catechin in enzyme activities and gene expression of antioxidative system in rat liver exposed to microwave. Nutr. Res., 22: 733 744.

7. Janchen JR and Frei MR. (1997): Body heating indueed by sub-resonant microwave irradiation: cardiovascular and respiratory responses in anesthetized rats. Bioelectromagnetics, 18:335 338.

8. Ryan KL. (1997): Age dose not affect thermal and 
cardiorespiratory responses to microwave heating in calorically restricted rats. Shock, 8:55 - 60 .

9. Kalns J, Ryan KL, Mason PA, Bruno JG Gooden $R$ and Kiel JL. (2000): Oxidative stress precedes circulatory failure induced by microwave heating. Shock, 13:52-59.

10. Jeong IT, Hwang SG, Park NG, Jung YR, Shin SI, Shoi SD and Park DK. (2003): Antioxidative effect of catechin on carbon tetrachloride induced hepatic injury in rats, Toxicology, 187:67 $-73$.

11. Lin CF, Lin CH, Lin CC, Lin YH, Chen CF, Lin CK and Lin YH. (2004): Antioxidative natural product protect against econazole - induced liver injuries. Toxicology, 196:87-93.

12. Wang HH, Hung TM, Wei J, And Chiang AN. (2004): Fish oil increases antioxidant enzyme activities in macrophage and reduces atherosclerosis Lesion in apo E-Knockout mice. Cardiovasc. Res., 61:169 - 176.

13. Sakanaka S, Kim M, Tuniguchi $M$ and Yamamoto T. (1989): Antibacterial substances in japanese green tea extract against streptococcus mutans, a carcinogenic bacterium. Agric. Biol. Chem., 53:2307 -2311.

14. Nakayama T. (1994): Suppression of hydroperoxide induced cytotoxicity by polyphenol. Cancer, Res., 7:1991-1993.

15. ELnimer T, EL-Kholy $R$ and EL-Gharib M. (2001): A study of the possible hazards of acute and chronic exposure to microwaves in albino rats. Bull. Egypt Soc. Physiol. Sci., 21(2)61 - 96.

16. Matuzaki T, and Hata Y. (1985): Antioxidative activity of tea leave catechin. Nippon Nageikagaku Kaishi., 56:129-134.

17. Choi J., Rhee S. Kim J. and Kim S. (1997): Cytochrome P 450 Contents, NADPH-Cytochrome P450 rductase activity of liver in rats exposed to microwaves. Korean J., 7 (3): 42 - 47.

18. Omura $T$ and Sato R. (1964): The carbon monoxide binding pigment of liver microsome. J Biol Chem ., 239 : 2370 -2378.

19. Mastars B, WilliamsC and Kain H. (1967): The preparation and properties of microsomal TPNH cytochrome c reductase from pig liver. Methods Enzymol., 10 : 551 - 573.

20. Marklund $S$ and Marklund $G$. (1974): Involvement of superoxide anion radical in the antioxidant of pyrogallol and convenient assay for superoxide dismutase. Eur. J. Biochem, 47:469 - 474.

21. Lawrence $R$ and Burk R. (1976): Glutathione proxidase activity in selenium deficient rat liver. Biophys Res Commun. 71: 952 958.

22. Azzi A, Montecucco $C$, and Richer C. (1975): The use of acetylated ferricytochrome $\mathrm{C}$ for the detection of superoxide radical produced in biological membrane. Biochem Biophys Res Commum. 65:597 - 603.

23. Satoh K. (1973): Serum lipid peroxide in cerbrovascular disorders determined by a new 
colorimetric method. Clin Chim.

Acta., 90 : 265 - 275.

24. Kim M and Rhee J. (2004): Green tea catechins protect rats from microwave- Induced oxidative damage. J Med food. 7 (3): 299 - 304.

25. Lowry $O$, Rosebrough $N$, Farr A and Randall R. (2004): Protein measurement with the follin phenol reagent J. Biol Chem., 193: 265 - 275.
26. Lu ST, Michaelson SM and Pettit S. (1983): Increased serum enzyme activity in microwave exposed rats. Radiat Res., 96:152 - 159.

27. Chou C, Cuy A, Bornemanl, Kumzl and Kramar P. (2004): chronic exposure of rabbits to 0.5 $\mathrm{m} \quad \mathrm{W} / \mathrm{cm} 2$ 2450-MHz CW microwave radiation, bioelectrmagnetics., 4:63-77. 


$$
\begin{aligned}
& \text { دراسة عن التأثير الواقي لمادة الكاتثين الموجودة في الثاي الأخضر } \\
& \text { على القلب المعرض لأثشعة الميكروويف المسببة للأكسدة } \\
& \text { في ذكور الفئران البيضاء } \\
& \text { محمود عبد الحمبي الغريب ، رومبياء علي الثربيني } \\
& \text { قسم الفسيولوجيا - كلية الطب - جامعة طنطا لعالئ }
\end{aligned}
$$

يهدف هذا البحث لدراسة تأثير مادة الكاتشين الموجودة في الثاي الأخضر على الثى

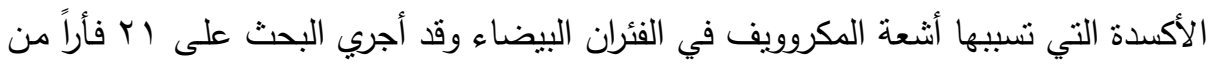
ذكور الفئران البيضاء التي قسمت إلى ثلاث مجموعات منساوية :

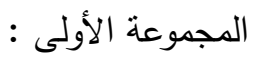
وهي المجموعة الضابطة .

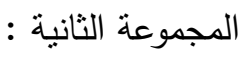

وقد تعرضت فيها الفئران لأشعة الميكروويف لددة 10 دقيقة ولفترة 7 أيام .

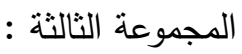

وقد تعرضت فيها الفئران لأشعة الميكروويف لمدة 7 أيام وأعطيت في أثناء هذه الفترة مادة

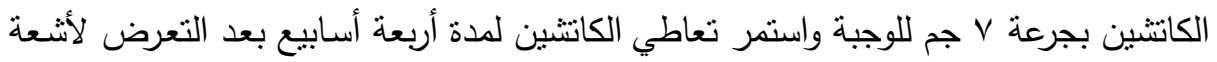

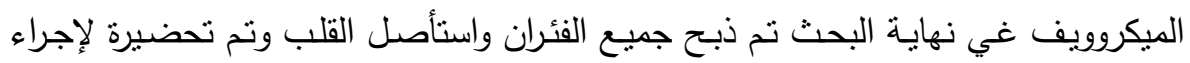
التحاليل اللازمة على الأنزيمات ومواد الأكسدة .

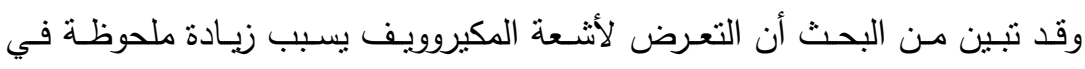
أنزيمـات السيتوكروم ب.0.

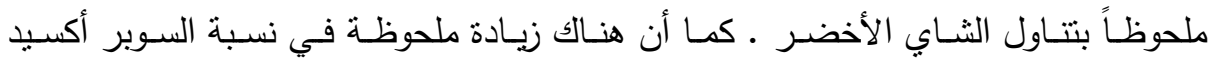
دسميوناز والليبيد بيروكسيد ونسبة الكربونيل في القلب والتي تتحسن بتتاول الثابي الأخضر كما أن هناك زيادة ذات دلالة إحصائية في نسبة الليبوفيوسين في القلب والتي تتحسن بإنطاء 
الثـاي الأخضـر وأيضـاً نقص في نسبة الجلوتـاثيون بيروكسيداز والكتـالاز والتـي تتحسن

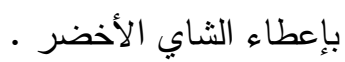

ويتضح من نتائج هذا البحث أنه بتتاول مادة الكاتثين الموجودة في الثشاي الأخضر

عند التعرض لأشعة الميكروويف التي تسبب نشاط جهاز الأكسدة في القلب وتكون المواد المؤكسدة في القلب تحمي القلب خطر هذه الأشعة وتقلل تكوين المواد المؤكسدة . 